\title{
The Most Ancient Ceramics of Baikal Siberia in the Context of the Traditions of Ceramics of East Asia
}

\author{
V.M. Vetrov ${ }^{\dagger}$, E. M.Ineshin
}

For citation: Vetrov V. M., Ineshin E. M. The Most Ancient Ceramics of Baikal Siberia in the Context of the Traditions of Ceramics of East Asia. Vestnik of Saint Petersburg University. History, 2019, vol. 64, issue 2, pp. 453-473. https://doi.org/10.21638/11701/spbu02.2019.205

Here we discuss research questions that arised in Siberian and the Russian Far Eastern archaeology due to discovery of the ancientmost ceramics. Usually study of ceramics and stone implements do not intercept. Lithic industries even if followed by ceramics are being discussed as Upper Paleolithic materials. Here we present previously unpublished data from Ust-Karenga archaeological complex along with the context of lithic industry. Description of the ancient ceramics is given in the context of archaeological materials from adjacent territories that contemporary to Ust-Karenga finds. Real links between these materials are established based on radiocarbon dating, mineralogy and micro element compositions of rocks used to manufacture diverse stone tools. Autors argue that the emergence of ceramic production took place in South China between 17,000-14,000 years ago. Then it spread northeast reaching Vitim and Chikoy basins when ceramic tradition holders started moving because of the late glacial environmental changes. Presumably, this might take place at around 13,000 years ago. New adaptation models such as fishing, food storage and necessity to use resources of vast had been challenged. This is in line with paleoathropological evidence and with the results of paleogenetics studies that indicate the southeastern origin of the mtDNA genome found for the bearers of the ancient ceramic tradition revealed in Siberia. Based on comprehensive evaluation of both lithic and ceramic component of archaeological context, authors see the necessity to revise the approach in search for cultural definition and principals of periodization in the Stone Age archaeology of Northern Asia.

Keywords: wedge-shaped cores, Siberia, late Pleistocene, glaciation, microblades, adaptation, three in one principle, ancient ceramics.

\section{Древнейшая керамика Байкальской Сибири в контексте традиций керамики Восточной Азии}

В.М.Ветров, Е. М. Инешин

Для цитирования: Vetrov V.M., Ineshin E.M. The Most Ancient Ceramics of Baikal Siberia in the Context of the Traditions of Ceramics of East Asia // Вестник Санкт-Петербургского университета. История. 2019. Т.64. Вып. 2. С. 453-473. https://doi.org/10.21638/11701/spbu02.2019.205

Evgeny M. Ineshin - PhD in History, Head of the Laboratory of Archeology, the Pedagogical Institute of the Irkutsk State University, 9, Sukhbaatar, Irkutsk, 664011, Russian Federation; ineshin.evgen@yandex.ru

Евгений Матвеевич Инешин - канд. ист. наук, зав. лаборатории археологии, Педагогический институт Иркутского государственного университета, Российская Федерация, 664011, Иркутск, Сухэ-Батора, 9; ineshin.evgen@yandex.ru

(c) Санкт-Петербургский государственный университет, 2019 
В статье рассмотрен круг вопросов археологии Сибири и Дальнего Востока России, появившихся в связи с открытием и постепенным вводом в научный оборот данных, относящихся к древнейшим свидетельствам керамического производства. Отмечено, что по настоящее время их значение не в полной мере оценено научным сообществом. Так, анализ керамики и каменного инвентаря до сих пор проводится раздельно, при этом каменные индустрии, сопровождающие ранние находки керамики, воспринимаются исследователями исключительно в качестве верхнепалеолитических. В статье представлены неопубликованные данные о керамических сосудах из Усть-Каренгского археологического комплекса и сопровождающем их каменном инвентаре. Древнейшая керамика Усть-Каренгского археологического комплекса описана в контексте одновозрастных археологических памятников прилегающих территорий. На основании данных радиоуглеродного датирования, изучения минералогического и элементного составов изделий из камня удалось выявить реальные связи, существовавшие между археологическими объектами в прошлом. В результате, сформулировано предположение о происхождении собственно керамического производства и о путях переноса данной традиции в бассейн Витима и Чикоя, а также и о ее носителях. Предполагается, что традиция керамического производства, сформировавшаяся около 17000-14000 л. н. в южных районах Китая, распространилась на рубеже 13000 лет назад в районы Северо-Востока Азии. Природно-климатическим фоном этого процесса служили условия позднего ледниковья, в контексте которых у местного населения формировались новые адаптационные механизмы (новый способ создания запасов пищевых ресурсов - рыболовство и высокая мобильность, необходимая для освоения обширных пространств небольшими группами охотников-собирателей). Данное предположение подтверждается как палеоантропологическими материалами, так и результатами изучения митохондриальной ДНК древнего населения региона. Носители традиции древнейшего керамического производства имеют юго-восточное происхождение. С позиций комплексной оценки каменного и керамического инвентаря в палеоэкологическом контексте сделан вывод о необходимости пересмотра подхода к выделению культур и принципов периодизации каменного века Северной Азии.

Ключевые слова: клиновидные нуклеусы, Сибирь, поздний плейстоцен, оледенения, микропластины, адаптации, принцип «три в одном», древняя керамика.

In the territory of modern Russia, the oldest ceramics was discovered in the early 1970s almost simultaneously in several places - in Primorye and the Amur River region (Hummi, Gassia, Ustinovka, Osipovka) ${ }^{1}$, in Transbaikal region (in the Chikoy river valley at Studenoe 1 sites) ${ }^{2}$ and in the Vitim river valley (Ust-Karenga XII, XIV, XVI, Yumurchen-VIII) ${ }^{3}$. At present, 18 reliable archaeological sites with ancient ceramics are known, which are provided with 77 radiocarbon dates ${ }^{4}$ (Fig. 1). Its discovery in Russia was preceded by similar finds in Japan, where about 100 archaeological sites with the evidence

${ }^{1}$ Zhushchikhovskaia I. S. Drevneishaia keramika: puti tekhnologicheskoi innovatsii // Vestnik DVO RAN. Arkheologiia. 2011. No. 1. P. 101-110.

${ }^{2}$ Razgildeeva I.I., Dai K., Ianshina O.V. Novye dannye o vozraste drevneishikh keramicheskikh kompleksov zapadnogo Zabaikal'ia // Evraziia v Kainozoe. Stratigrafiia, paleoekologiia, kul'tury. 2013. Iss. 2. P. 168-178; Tsydenova N., Andreeva D., Zech W. Early pottery in Transbaikal Siberia: New data from Krasnaya Gorka // Quaternary International. 2017. Vol.441. P. 81-90.

3 Kuzmin Y., Vetrov V. The earliest Neolithic complex in Siberia: the Ust-Karenga 12 site and its significance for the Neolithization process in Eurasia // Documenta Praehistorica. 2007. No. 24. P. 9-12.

4 Sato H., Natsuki D. Human behavioral responses to environmental conditions and the emergence of the worlds oldest pottery in East and Northeast Asia: An overview // Quaternary International. 2017. Vol. 441. P. 12-28. 
of technology of the most ancient ceramic have been discovered by now ${ }^{1}$. Subsequently, traces of ancient pottery are found in China (Xianjendong, Yuchanyan, Miaoyan) and in South Korea (e.g., Kozanni, Tomsandon, Kumenri) (Fig. 1). Reliable dates on ceramic complexes were obtained in the late 1980s and in the 1990s on organic materials from cultural layers (charcoal and bone), and with the development of AMS dating technology, they were largely confirmed by direct dating of organic residues included in ceramic paste and carbon deposits on dishware surface.

The most complete up-to-date radiocarbon data set is presented by Sato and Natsuki who made important and reasonable conclusions when discussing the question of spatio-temporal patterns observed in the Far East on the ancient pottery ware sites ${ }^{5}$, and we find it to be fully appropriate and reliable. Partly, these data are also used by Kuzmin ${ }^{6}$, however in that version they are not so detailed, and thus we follow mostly Sato and Natsuki $^{7}$ in further discussions.

Surprisingly, the discovery of the most ancient ceramics did not lead to careful consideration of the phenomenon of ancient ceramics in the professional community. In general, it was mostly expressed in validation of dates, re-dating of the materials in search of older periods and debate of their reliability ${ }^{8}$. Some of the researchers, including those who found the first contexts with really old ceramics, questioned their own findings, and thus the very fact of the existence of the ancient pottery ware was rejected ${ }^{9}$. For instance, the discovery of ancient ceramics in cultural horizons dated by the end of the Pleistocene by the radiocarbon method of coal from the centers of the settlements Studenoe-1 and Ust-Menza in Transbaikalia was first ignored by the discoverer, then presented as a kind of error in the method of dating or a specific feature of the object's stratigraphy. As a rule, researchers give a description of ancient ceramics with no connection to the analysis of stone and bone implements, or the latter are discussed superficially ${ }^{10}$.

There was also no understanding of the phenomenon of early ceramics in the context of validation of the criteria for definition of the boundaries for some of the taxons used in the archaeological periodization based on European materials when applied to the ar-

${ }^{5}$ Sato H., Natsuki D. Human behavioral responses to environmental conditions and the emergence of the worlds oldest pottery in East and Northeast Asia: An overview. P. 12-28.

${ }^{6}$ Kuzmin Y. V. The origins of pottery in East Asia and neighboring regions: An analysis based on radiocarbon data // Quaternary International. 2017. Vol. 441B. P. 29-35.

7 Sato H., Natsuki D. Human behavioral responses to environmental conditions and the emergence of the worlds oldest pottery in East and Northeast Asia: An overview.

8 Zhushchikhovskaia I.S. Drevneishaia keramika: puti tekhnologicheskoi innovatsii. P.101-110; Razgildeeva I. I., Dai K., Ianshina O. V. Novye dannye o vozraste drevneishikh keramicheskikh kompleksov zapadnogo Zabaikal'ia. P.168-178; Mylnikova L.N., Nesterov S.P. Fiziko-khimicheskoe issledovanie keramiki pamiatnika Kosanni: k probleme proiskhozhdeniia goncharstva // Neolit i neolitizatsiia basseina Iaponskogo moria: chelovek i istoricheskii landshaft: Vladivostok, 2008. P. 161-165.

9 Konstantinov M. V.: 1) Kamennyi vek vostochnogo regiona Baikalskoi. Ulan-Ude; Chita, 1994; 2) "I opyt, syn oshibok trudnykh" (problemy opredeleniia vozrasta drevnikh poselenii Zabaikal'ia) // Drevnee Zabaikale: kul'tura i priroda. Chita, 2009. P. 35-42.

${ }^{10}$ Kuzmin Y. V. The origins of pottery in East Asia and neighboring regions: An analysis based on radiocarbon data // Quaternary International. 2017. Vol.441B. P. 29-35; Razgildeeva I. I., Dai K., Ianshina O. V. Novye dannye o vozraste drevneishikh keramicheskikh kompleksov zapadnogo Zabaikal'ia // Evraziia v Kainozoe. Stratigrafiia, paleoekologiia, kul'tury. 2013. Iss. 2. P. 168-178; Tsydenova N., Andreeva D., Zech W. Early pottery in Transbaikal Siberia: New data from Krasnaya Gorka // Quaternary International. 2017. Vol.441. P. 81-90; Sato H., Natsuki D. Human behavioral responses to environmental conditions and the emergence of the worlds oldest pottery in East and Northeast Asia: An overview. P. 12-28. 


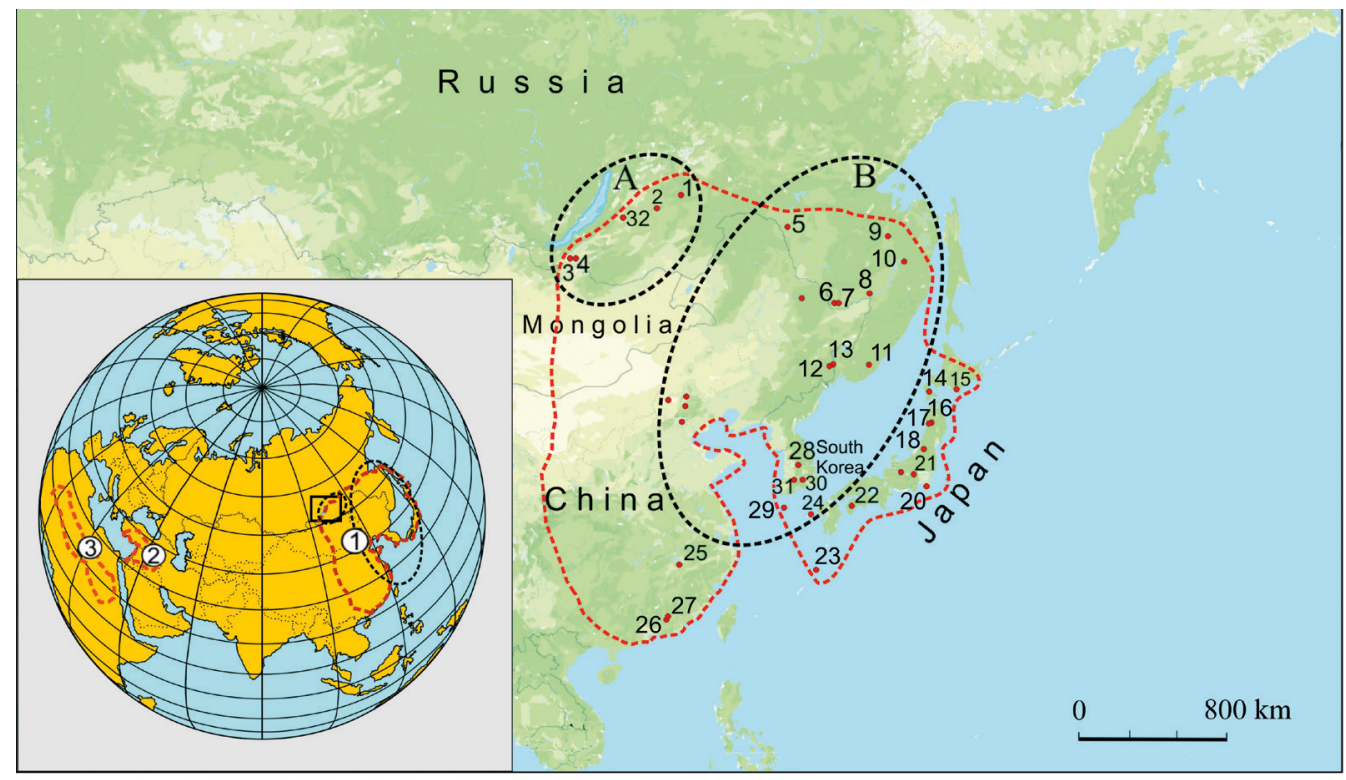

Fig. 1. Map of archaeological sites with ancient ceramics in East Asia:

1 - Ust'-Karenga 2, 14, 16; 2 - Ust'-Umyrchen 8; 3 - Studenoe 1; 4 - Ust'-Menza 1; 5 Gromatukha; 6 - Goncharka 1, Osinovaya rechka, Gasha; 7 - Novotroitskoe; 9 - Yamikhta; 10 - Khummi; 14 - Odai-Yamamoto I; 17 - Kiwada; 18 - Takihata; 19 - Kubodera-minami, Tako-minamihara, Jin., Unoki-minami; 20 - Kuzuharazawa IV, 2-Seiko-sanso, Gotenyama 2N, Shoanfujisawa campus, Tsukimino-kamino loc. 2, Nozawa; 21 - Gotenyama 2N; 22 - Kamikuroiwa; 23 - Sankakuyama; 24 - Fukui cave, Senpukuji; 25 - Xianrendong; 26 - Zengpiyan; 27 Yuchanyan; 28 - Osanni; 29 - Gosanri; 30 - Tonsamdon; 31 - Posanni; 32 - Krasnaya Gorka; 33 - Nanzhuangtou; 34 - Donghulin; 35 - Zhuannian; 36 - Yujigou.

Red dashed line marks the area of the Far Eastern province of the ancient ceramics, within which continental (A) and coastal zone (B) are distinguished and indicated by black dashed contours. Low left corner: worlwide distribution of the ancient ceramics - East Asian province (1), West Asian, or Near Eastern center (2), and North African province (3) (illustration by E. Ineshin)

chaeology of Asia. The fact of ancient ceramics has not been appreciated in terms of understanding human adaptations at the end of the Pleistocene in North Asia. If in Europe the emergence of ceramics is appraised as a marker of the Neolithic and related changes in the economic and ideological spheres, then how, in light of the new evidence on the ancient ceramics dating, can we assess the end of the Pleistocene in the East of Asian? Was its ceramics Paleolithic, Mesolithic? Pleistocene Neolithic? How to evaluate, in the light of the latest datings of the oldest ceramics in southeastern China, the late Paleolithic in North Asia? What did the manufacture of ceramics mean in terms of primitive economy? Cooking? Stockpiling and canning? What was the original shape of ceramic vessels and what were their changes associated with? What do the earliest forms of ornaments reflect? And so on. All these questions remain outside the scope of discussion.

Among known archaeological sites with ancient ceramics, the Ust-Karenga archaeological complex stands quite apart ${ }^{11}$. It is the largest and most studied of the objects with

11 Vetrov V.M. Drevneishie sledy keramicheskogo proizvodstva v Vostochnoi Azii // Antropogen. Paleontropologiia, geoarkheologiia, etnologiia Azii. Irkutsk, 2008. P. 28-34. 


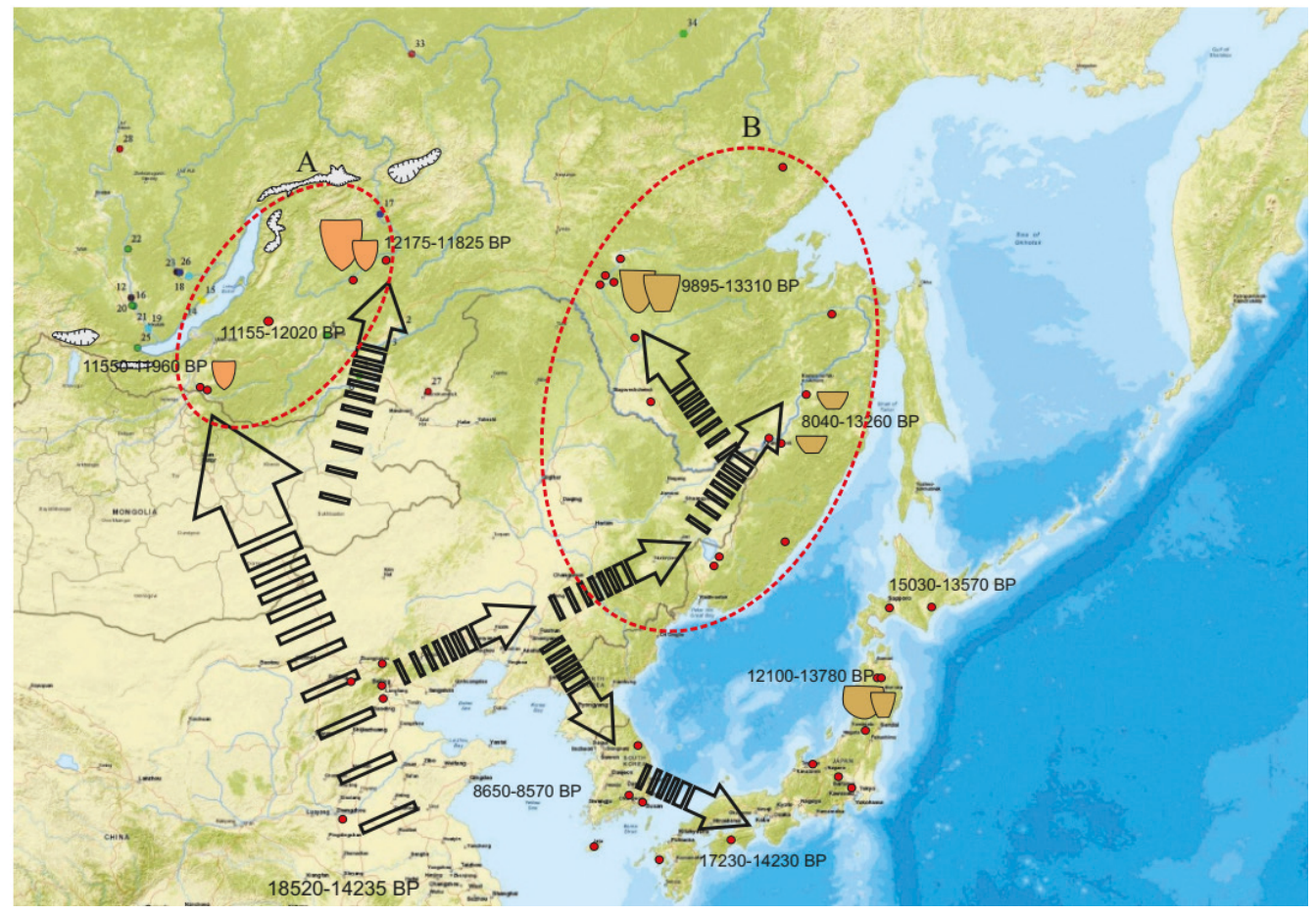

Fig. 2. East Asian center of the emergence and development of the ceramics production, and possible directions of its spread into coastal continental zone, respectively.

A - continental zone of the most ancient ceramics production; B - coastal zone of the most ancient ceramics production (map by E.M. Ineshin)

the oldest ceramics on Vitim (Ust-Yumurchen VIII, Ust-Oktorokon). The peculiarity of archaeological monuments with the oldest ceramics on Vitim are their layering and proximity to other archaeological objects which are synchronous to them, being also multilayered, but with no ceramics in the collection. There have been established connections between a part of archaeological objects with ceramics and without it, which are reliably documented by the observed facts of the transfer of rare types of stone raw materials, and are confirmed by the analytical results of various methods ${ }^{12}$. Following A. A.Zinoviev $^{13}$, by connections we mean "matter or energy transfer" hereafter. In the Ust-Karenga archaeological complex, ancient ceramics was recorded in various cultural horizons included in alluvial and subaerial deposits formed over a long chronological interval of 11,240-6,890 years ago (Fig. 2), which was not observed at any other archaeological site in East Asia (uncalibrated radiocarbon ages are used hereafter).

Practically, this is the only archaeological site where the oldest ceramics is fixed in a multi-layered position, which makes it possible to follow both the development of manufacturing technology, changes in the shape of vessels, functional use and ornamentation

12 Vetrov V.M., Ineshin E.M., Revenko A. G., Sekerin A.P. Artefakty iz ekzoticheskikh vidov syria na arkheologicheskikh pamiatnikakh Vitimskogo basseina // Baikalskaia Sibir' v drevnosti. 2000. Iss. 2, part 1. P.98-117.

13 Zinovev A. A. Na puti k sverkhobshchestvu. Moscow, 2000. P. 260. 
through time, and changes in the stone inventory accompanying ceramics as well. After $6890 \pm 80{ }^{14} \mathrm{C}$ BP, the oldest type of ceramics was replaced by another type, and changes occurred in sets of stone implements, expressed in the transition to another way of flaking system for blade cores (from wedge-shaped to prismatic) with the simultaneous switch to different raw material ${ }^{14}$. The final dating of ceramics of the most ancient type is of particular importance to us, as it enables, on well-documented grounds, to include the materials from human burial on Lower Dzhilinda (Sivakon) into a circle of objects that are synchronous to ancient ceramic production. In turn, this circumstance allows to proceed to a discussion of the issues of anthropology and paleogenetics of the ancient potters of Asia. This is the only case so far that makes it possible to include some new information in the analysis.

It is conceivable that ancient ceramics was also present in Studenoe 1 and Ust-Menza 1 stratified sites, but the very fact of finding it was ignored due to the methodology used by the excavators, and thus such finds had not been even mapped. Currently, there are only brief descriptions published tardily, on the two cultural horizons of these objects, including the dating of cultural remains, data on the form and technology of manufacturing the oldest vessels from the Chikoy valley ${ }^{15}$.

The remains of ceramic vessels of the most ancient type (as a rule, their upper parts), were recorded in separate loci at the Ust-Karenga archaeological complex, precisely at locality III, XII, XIV and XVI. Ceramic-bearing layer of these stratified sites recognized as 'combined cultural horizon 7' was detected on the vast area. Its end points are at a distance of $1500 \mathrm{~m}$ from each other, and thus, presumably, the area covered by the horizon 7 between localities XII, XIV, and XVI counts to $1,7 \times 10^{5} \mathrm{~m}^{2}$, of which only $822 \mathrm{~m}^{2}$ of which have been excavated. These local points do not constitute a single settlement with a common structure, and the allocation of so-called the $7^{\text {th }}$ cultural horizon with ancient ceramics at each of the localities is, to some extent, a simplification based on the general position of the horizon with cultural remains in the top of alluvial bedded river sands covered by thin-layered fine grained lacustine sands. The difference in elevation between separate localities that contain horizon 7 exceeds $3 \mathrm{~m}$ in height, yet this level is termed 'the $7^{\text {th }}$ cultural horizon (combined horizon)'. At Ust-Karenga XII site, cultural remains are also recorded below the level 7, in 8 and $8 \mathrm{~A}$ horizons occurring in the alluvial deposits that underlie it. However, no ceramics belongs to them so far, which is probably due to the small area of excavation ${ }^{16}$. It should be noted that in terms of lithic technology (knapping technology and tool typology) there is no difference between the $7^{\text {th }}$ cultural horizon, on the one hand, and 8 and $8 \mathrm{~A}$ horizons, on the other.

So far, only two horizons of those which yielded the oldest ceramics are characterised by radiocarbon dates on charcoal samples from the hearth and on organic residues respectively. The Horizon 7 at Ust-Karenga XII dates to $11,240 \pm 180{ }^{14} \mathrm{C}$ years BP, and the $5^{\text {th }}$ cultural horizon at Ust-Karenga III dates to $6890 \pm 80{ }^{14} \mathrm{C}$ years BP. Additionally, two more dates were obtained on organic component of ceramic paste from Ust-Karenga

14 Vetrov V.M. Drevneishie sledy keramicheskogo proizvodstva v Vostochnoi Azii. P. 28-34.

15 Razgildeeva I. I., Dai K., Ianshina O. V. Novye dannye o vozraste drevneishikh keramicheskikh kompleksov zapadnogo Zabaikal'ia. P. 168-178.

${ }_{16}$ Hommel P.N., Schwenninger J.-L., Ineshin E.M., Vetrov V.M. Testing times: an evaluation of the radiocarbon chronology for early ceramic vessel production at Ust'-Karenga // Izvestiia laboratorii drevnikh tekhnologii. 2017. Vol. 13, no. 1. P.31-46. 
XII. These are $11065 \pm 70(\mathrm{AA}-38101)$ and $10600 \pm 110(\mathrm{AA}-21378)^{17}$ that come from the $7^{\text {th }}$ (combined) cultural horizon. Finally, OSL dating performed on quartz grains extracted from the ceramic paste produced the age of 11240 years ago.

Research done on previously received radiocarbon dates on charcoal samples that come from the hearth fill allowed to recognize problems in methodological approach used for sampling. Because of that, older dating results are considered erroneous, and we therefore use the chronology based on the newest AMS ${ }^{14} \mathrm{C}$ dating results performed on organic inclusions extracted from the ceramic paste. These dates have a good relationship with the dating of catastrophic geological event, which is well recognizable in the regional stratigraphic record. This is the formation of Muya dammed lake that left well-expressed signature at Ust-Karenga archaeological complex. Its lithostratigraphic sequence contains a deposit of fine grained thin-bedded sand which is up to $1,4 \mathrm{~m}$ thick. This sand deposit overlays culture-bearing deposits, namely horizons 8 and $8 \mathrm{~A}$, and combined horizon 7 .

Lacustrine genesis of these deposits is reliably established by pollen and diatom record that indicates formation of diatomic associations in the cold environment of stagnant deep-water reservoir. Radiocarbon dates obtained by D. Kunikita on organic inclusions sampled from ceramic fragments of three different ceramic vessels that come from three different locations at Ust-Karenga site complex indicate that the human habitation and ceramic production took place at about 12000 years ago - $11870 \pm 40$ (TKA-19744, locality XVI), $11825 \pm 45$ (TKA-19745, locality XII, vessel 1), and $12175 \pm 40$ (TKA-19743, locality XII, vessel 2$)^{18}$.

These ages pre-date the formation of Muya dammed lake, which is reliably dated to $11770 \pm 40$ (Beta-432243). This date is received by dating the larchwood sample obtained from the burried forest horizon in the central part of the former lake ( the external part of the larchwood stem was sampled within the latest growth zone of the last five year-rings, which makes the dating result solid). Thus, time of the formation of the combined culture-bearing horizon (horizon 7) in different areas can be estimated as 350 years at least.

Year-ring structures observed on the samples of the buried larchwood forest indicate extremely cold and dry conditions with low-water stage of the river development that lasted for 200 years prior to the formation of Muya dammed lake and thus precisely demonstrate environmental conditions at the time of the formation of the combined horizon 7.

In general, the geological age of the ceramics and cultural remains from different horizons of the Ust-Karenga complex is supported by 24 age determinations, 21 of which are radiocarbon dates and three produced by OSL dating ${ }^{19}$. This is a large data set, but for years all kinds of errors and/or misinterpretations have occurred ${ }^{20}$, and then this needs to be discussed extensively. At present, we can agree with the above given chronology that is based on direct dating of the early ceramics of the horizon 7 at Ust-Karenga and which is

${ }^{17}$ Kuzmin Y., Vetrov V. The earliest Neolithic complex in Siberia: the Ust-Karenga 12 site and its significance for the Neolithization process in Eurasia. P. 9-20.

18 Sato H., Natsuki D. Human behavioral responses to environmental conditions and the emergence of the worlds oldest pottery in East and Northeast Asia: An overview. P. 12-28.

${ }^{19}$ Hommel P. N., Schwenninger J.-L., Ineshin E.M., Vetrov V.M. Testing times: an evaluation of the radiocarbon chronology for early ceramic vessel production at Ust'-Karenga. P. 31-46.

${ }^{20}$ Kuzmin Y. V.: 1) The origins of pottery in East Asia and neighboring regions: An analysis based on radiocarbon data. P. 29-35; 2) Proiskhozhdenie keramiki v Evrazii: sovremennoe sostoianie voprosa // Rossiiskii arkheologicheskii ezhegodnik. No. 3. 2013. P. 8-26. 
in agreement with geochronological data and history of sedimentation revealed for this site as demonstrated (see above).

In the Ust-Karenga archeological complex, the type of the most ancient ceramics appears to be of well-developed form as it is found among the materials yielded by the combined $7^{\text {th }}$ cultural horizon as well as by the finds from the overlying cultural horizons 6 through 3. In cultural horizons 3 and 4, finds of the ancient ceramic type are few and can be considered as potentially redeposited because the stratigraphy of these finds is not absolutely clear.

The cultural remains of the most ancient $7^{\text {th }}$ horizon are sealed within thin $(1-3 \mathrm{~cm}$ thick) layer of alluvial sand of dark color within the area where finds are concentrated, with inclusions of small charcoals, possibly washed out from the eroded hearth. As a rule, in the center of such concentrations there is a hearth with no construction, with small fragments of burned bone and products of combustion in the form of a carbonaceous-ash mass eroded from the hearth and distributed across the habitation area. Outside it, the alluvial layer does not contain carbonaceous inclusions, is not colored, and in the cross-section is visually practically indistinguishable from the alluvial thin-bedded sands of different (lacustrine) genesis that overlay it. This is eloquently indicated by the state of the ancient pollen from the cultural-stratum layer itself and the overlying sediments. According to the conclusion of a palynologist N. V. Kulagina, pollen grains from the lake alluvial sands overlapping the $7^{\text {th }}$ cultural horizon are damaged, do not have an integral form; pollen contains grains clearly redeposited from much more ancient sediments of Tertiary age. This can be explained only by the deposition of pollen grains under conditions of dammed lake, high water stand and erosion of older sediments along the sides of the valley with subsequent re-deposition of the pollen grains contained in them.

This indicates a sharp change in depositional regimes in the Ust-Karenga part of the Vitim valley caused by catastrophic geological events and the emergence of a giant dammed lake in the river valley that also penetrated into its tributaries ${ }^{21}$. This event is reliably documented by the buried forest (Sukhakit "stump" horizon) in the proposed center of the formation of a dammed lake reservoir in the Muya-Kuandin depression $340 \mathrm{~km}$ downstream in the Vitim river from the Karenga river mouth. Radiocarbon dating performed on burried trees sampled by each five year rings produced ages of $11780 \pm 40$ years ago (Beta-432243), which is consistent with the age of cultural remains of the $7^{\text {th }}$ combined cultural horizon. The thickness of the lake alluvium, which overlaps the $7^{\text {th }}$ combined cultural horizon, varies from site to site and changes from 0.4 to $1.4 \mathrm{~m}$. In fact, that facilitated good preservation of cultural remains and spatial structure of human settlements, close to the in situ state. However, this was not favourable for the preservation of bones, of which only small burnt fish bones and fragments of mammal bones were preserved. Cultural remains of the $6^{\text {th }}, 5^{\text {th }}, 4^{\text {th }}$, and $3^{\text {rd }}$ horizons belong to subaerial deposits, formed after the emptying of the dammed lake about $10260 \pm 220$ (Ri-202), when this surface came out of the accumulation mode of bottom sediments of the lake and river type ${ }^{22}, 18$. According to geologists, this giant dammed lake, whose maximum area and volume belonged to

21 Kulchitskii A.A., Skovitina T.M., Ufimtsev G.F. Plotinnye ozera v dnishchakh riftov Vostochnoi Sibiri: svidetel'stva iz proshlogo i veroiatnost' v budushchem // Geografiia i prirodnye resursy. 1997. No. 1. P.61-65; Margold M., Jansson K.N. Glacial geomorphology and glacial lakes of central Transbaikalia, Siberia, Russia // Journal of Maps. 2011. Vol. 7 (1). P. 18-30.

22 Vetrov V. M. Drevneishie sledy keramicheskogo proizvodstva v Vostochnoi Azii. P. 28-34. 
Muya-Kuandin depression ${ }^{23}$, existed for about 1500 years $^{24}$. This explains the absence of cultural remains in the lake alluvium at the Karenga river mouth and the reappearance in this area of the carriers of the oldest ceramics' culture at level 6, with a significant time gap. The time gap is the interval between the dates on the seventh cultural horizon of $11825 \pm 45$ (TKA-19745) and horizon 6, which is somewhat older than the $6890 \pm 80$ (LE-1961) as can be concluded by dating the fifth cultural horizon.

At present, the combined collection of the Ust-Karenga archaeological complex includes 1330 fragments of the oldest type of ceramics that belong to 35 vessels. This makes it possible to reconstruct both the shape and the manufacturing technology and the main decoration patterns. In fact, this is the largest number of fragments of the oldest ceramics obtained from any archaeological site in Russia. The degree of completeness of representation of each vessel enables to restore ornamental compositions for 24 vessels, in addition to their shape, which is more than $68 \%$ of the total number of ceramics (Fig. 3). This significantly increases the information value of this source.

In the planigraphy of the sites of Ust-Karenga complex, concentrations of pottery ware fragments are always confined to accumulations of the stone waste material near the hearth, which form oval concentrations of cultural remains with typical dimensions of $4 \times 5 \mathrm{~m}$ with inclusions of small charcoal pieces in matrix sediments. Among the forms of the pottery ware, there are two groups: large vessels of a simple open ovoidal shape with a pointed bottom with a volume of 8 to 10 liters, and smaller vessels of the same simple open expressive ovoidal shape with a pointed bottom of a volume from 1 to 1.5 liters. Almost no vessel has any traces of soot, while some large vessels bear the evidence of repair attempted by means of drilling holes on both sides of the crack and stitching the parts, most probably with organic fibers. The latter may support the assumption that at least large vessels were used for storage of dry bulk or thick viscous products such as fat, pickled fish, or as containers for products of plant origin (Fig. 4).

Given the size of the vessels and their technical parameters, it is difficult to assume that their owners travelled long with them. It is logical to suppose that the manufacture and use of vessels occurred directly on the habitation site and was confined to sites with a relatively permanent occupation, where pottery ware was used as containers for storing food supplies. Vessels of the same size, decoration and manufacture technique were found in the $3^{\text {rd }}$ cultural horizon of the location of Ust-Yumurchen VIII in Vitim river valley near proposed margin of Muya dammed lake, about $180 \mathrm{~km}$ upstream from Ust-Karenga group of archaeological sites. Few fragments of the same pottery ware were found at Oktokoron site $25 \mathrm{~km}$ upstream in the Vitim river valley. A similar form of vessels and dimensions were discovered from the $8^{\text {th }}$ cultural horizon of Studenoe 1 settlement and in the $8^{\text {th }}$ cultural horizon of Ust-Menza 1 site in Chikoy river valley ${ }^{25}$, albeit nothing is known about their decoration pattern.

In the Ust-Karenga archeological complex, vessels were made by the zonal-paste method with the initial formation of the bottom part in the form of a funnel with a point-

${ }^{23}$ Margold M., Jansson K. N. Glacial geomorphology and glacial lakes of central Transbaikalia, Siberia, Russia. P. 18-30.

${ }^{24}$ Kulchitskii A.A., Skovitina T.M., Ufimtsev G.F. Plotinnye ozera v dnishchakh riftov Vostochnoi Sibiri: svidetel'stva iz proshlogo i veroiatnost' v budushchem. P. 61-65.

${ }_{25}$ Razgildeeva I. I., Kunikita D., Yanshina O. V. Novye dannye o vozraste drevneishikh keramicheskikh kompleksov zapadnogo Zabaikal'ia. P. 168-178. 


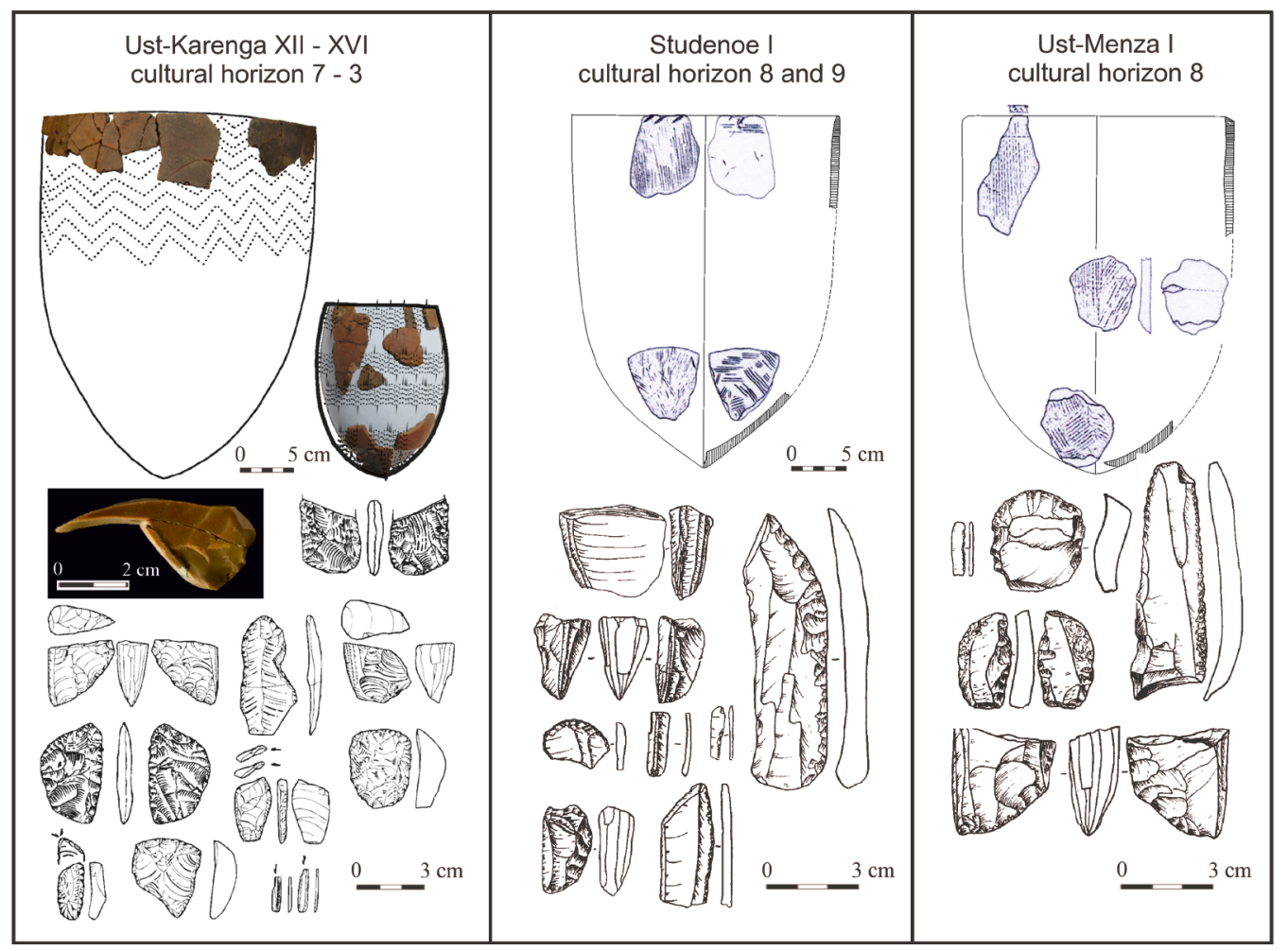

Fig. 3. Ceramics and lithic material from pottery-bearing archaeological contexts of different archaeological objects, left to right: Ust-Karenga XII-XVI, cultural horizons 7 to 3 [Vetrov, 2008]; Studenoe I, cultural horizons 8 and 9, and Ust-Menza I, cultural horizon 8 (modified from [Konstantinov, 1994] (lithic material) and [Razgil'deeva, Kunikita, Yanshina, 2013] (ceramics))

ed end. All vessels of the combined collection have a pointed bottom, a wide mouth, and slightly convex walls that form a simple ovoidal truncated shape. The rim diameter $\mathrm{s}$ is a little smaller (by 5-10 $\mathrm{mm}$ ) than the maximum diameter of the body, which causes a certain closure of the shape. As already mentioned, the volume of vessels varies from 1.5 to 9 liters, which indicates different functions as well as a possible degree of mobility of owners of vessels of such volume. The walls of the vessels are thin, with stable thickness which never exceeds $5 \mathrm{~mm}$. The paste is dense with the addition of granitic subsoil and organic residues visible on scraps and cleavages in the form of traces of burnt grass fragments of sedge grass plants, and, rarely, animal hair. Thin patches of the future vessel stuck to each other with a slight baselap, after which they were probably molded by extrusion, as is evidenced by the position of particles of organic residues and grains of granitic subsoil on breaks and in cleavages.

After the main body of the vessel was made, it was dried. Then a rim, made in the form of a narrow coil, would be attached, and the external surface was smoothed with liquid clay. The inner surface of the vessels was also rubbed with a solution of liquid clay using a bundle of sedge grass plants. This operation leaves characteristic marks in the form of horizontal scratches and grass imprints on the surfaces of the vessel walls. After that, 

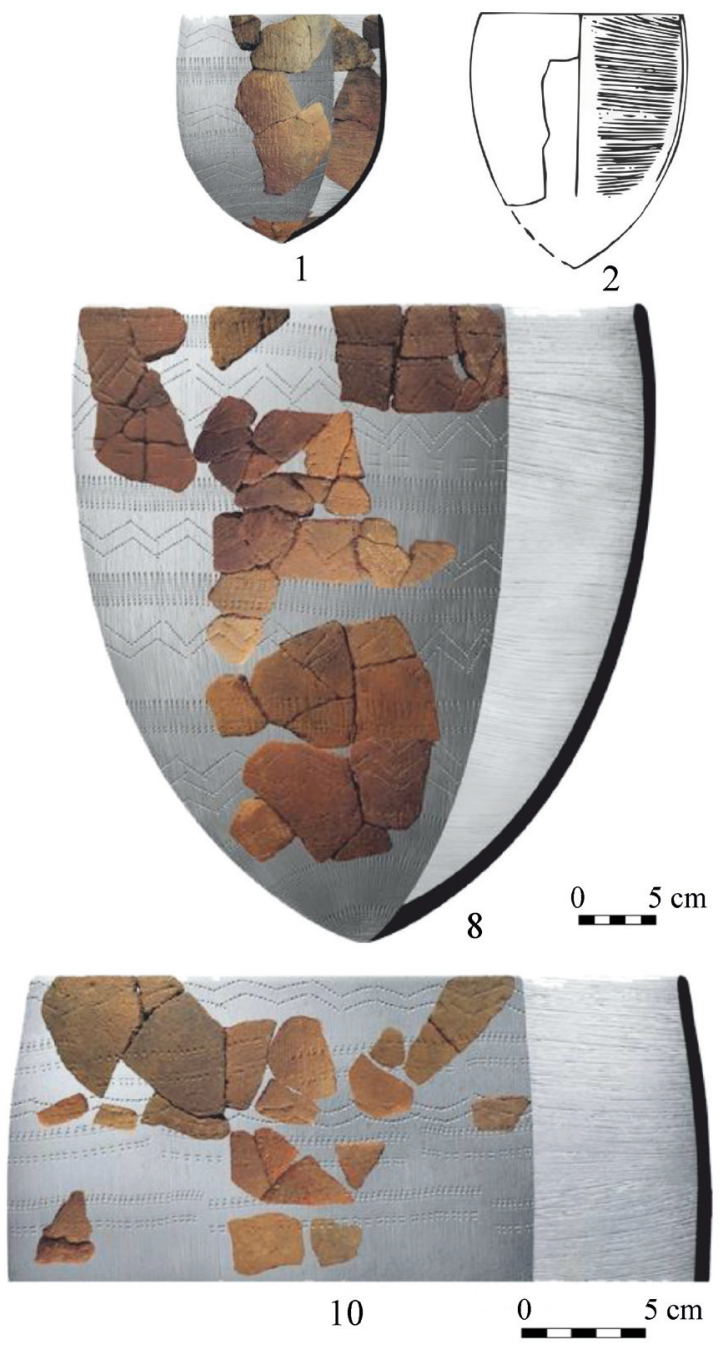
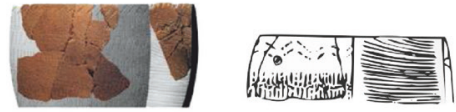

3

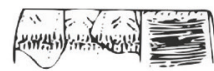

5

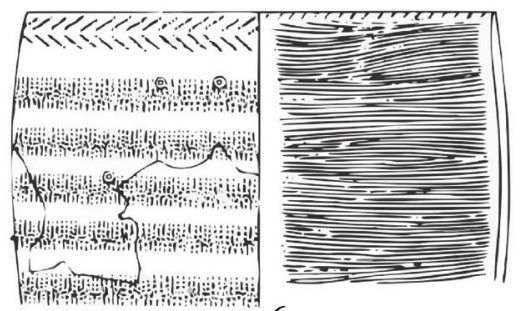

6
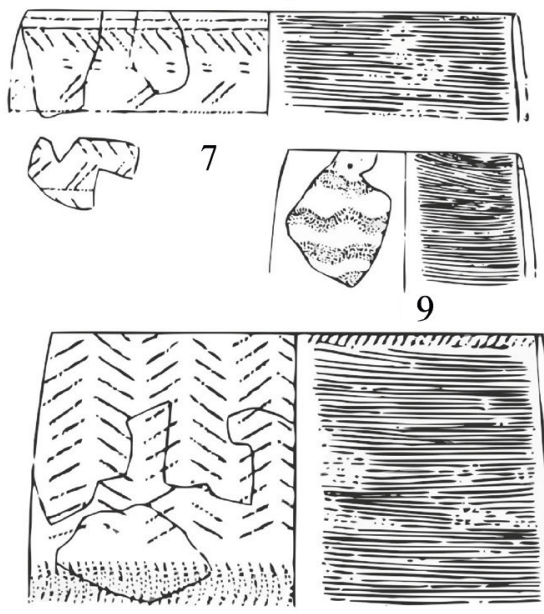

11
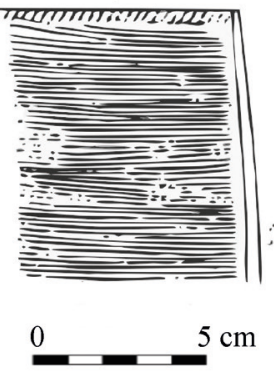

Fig. 4. The most ancient ceramics from Ust-Karenga geoarchaeological complex, combined cultural horizon 7, and cultural horizons 6, 5, 4. General shape of the vessels and ornamental compositions (drawing by E. M. Ineshin)

decoration was applied to the wet external surface with an indented stamp in the form of a small scapula with a denticulate edge. When stamped on clay, it produces a comb stamp. The ornamentation, as already noted, was applied with a comb stamp in the form of horizontal rows of zigzag lines, in which the starting and ending points of the indented stamp imprint had a slightly larger impression depth. This is well-known "stepping comb" ornamentation (see Fig. 4) extremely wide spread in the northern Eurasia ${ }^{26}$.

The ornamentation could be supplemented with horizontal dashed lines or horizontal zigzag rows of the same stamp. In some cases, it was supplemented by inclined depressions of the tip of the same denticular stamp made around the rim either from the outside

${ }^{26}$ Vetrov V.M. Drevneishie sledy keramicheskogo proizvodstva v Vostochnoi Azii. P. 28-34. 
or from the inside (see Fig. 3, 4). The analysis of the micro-traces and peculiarities of the stamp made it possible to conclude that one vessel was ornamented by the same tool but in a different technique of making prints. After all, the vessels were baked in a fire at sufficiently high temperatures, which produced high-quality thin-walled vessels with pointed bottom and the outer walls of a light brown color. Often, the decoration covered the entire body of the vessel from the rim to the bottom (see Fig. 3, 4). Of the total volume of reconstructed vessels, only one copy had no decoration.

Regarding the origin of this type of ornament, its stable repeatability, it can be assumed that an indented stamp and its type ("stepping comb") imitated a line of stitches, fastening parts of leather or bark parts of containers that served as the prototype of ceramic vessels. Ethnographic objects like bast baskets, panniers, pouches and other items of the same function are common among taiga hunters and reindeer herders of Siberia. Interestingly, they all have a characteristic feature as tack welds connecting various parts of the object usually play a decorative role and provide additional aesthetic properties. In that sense, decoration patterns observed on pottery could have been inherited from traditional containers of all kinds made of organic materials, which were already in use. However, in ceramics they received additional quality, such as waterproof walls, the possibility of being placed in a fire or on coals for the purpose of cooking, and the ability to have safely sealed container.

Based on actualistic approach, one can put forward a hypothesis about the formation in the mountain-steppe regions of the Baikal-Patom Highland and the Vitim Plateau an economic model with a base camp-site and a number of temporary camps. At the base sites, a part of the population lived permanently, while mobile groups of hunter-gatherers could organize temporary/seasonal camps for harvesting different kinds of supply to support the inhabitants of the base site. It could take tens and even hundreds of kilometers to travel between base site and temporary/seasonal camps.

Only in this case, we can find a noncontradictory explanation for the presence in the same region (the Vitim river basin) contemporaneous archaeological sites with and without ceramics. They are found at a considerable distance from each other, but clearly have some connections, which is seen, in addition to shared tradition of manufacture of stone tool production, by use of rare, or exotic, rocks as raw material (graphite, jasper, volcanic pumices, quartz crystal) transported from original source areas to archaeological $\operatorname{sites}^{27}$ (Fig. 5). The genesis and geographic location of such areas indicates its compact local distribution, which does not go further than the first tens of kilometers. Consequently, its exploitation and movement in space over long distances could only be carried out by human teams, within which there was an idea of the beneficial use of these minerals and the position of their sources, transmitted over generations. It can also serve as another, though indirect, confirmation of the stability of the ancient population, within which not only specific ceramic traditions survived and allowed to maintain production of the ancient type of pottery ware, but also as the confirmation that the knowledge of stone processing and the choice of specific lithic raw material for certain types of the artifacts were transmitted.

27 Vetrov V.M., Ineshin E.M., Revenko A.G., Sekerin A.P. Artefakty iz ekzoticheskikh vidov syr'ia na arkheologicheskikh pamiatnikakh Vitimskogo basseina. P.98-117; Demonterova E.I., Ivanov A.V., Ineshin E. M., Tetenkin A. V. K voprosu o mobil'nosti drevnego naseleniia severa Baikal'skoi Sibiri v kontse pleistotsena // Stratum plus. 2014. No. 1. P. 165-180. 


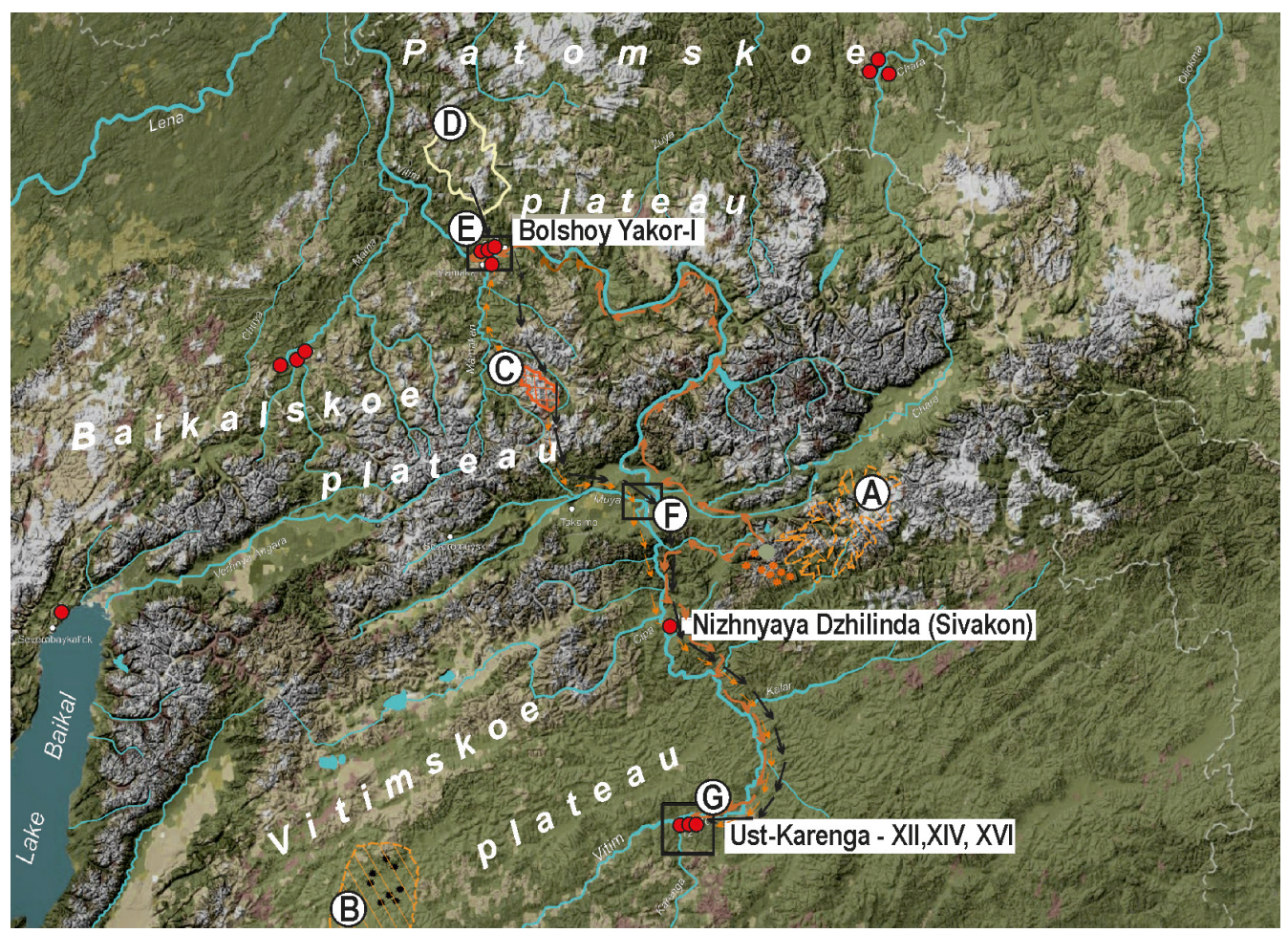

Fig. 5. Long-distance transportation of exotic lithic raw materials in Baikal-Patom highlands and Vitim plateau.

A - Udokan volcanic plateau, Trakhit volcano pumic stone source; C - Kelyan suit, brownish jasper source; D - Takhtygin field of graphite rock, raw material source; E - Bolshoi Yakor complex of archaeological objects (Bolshoi Yakor I, Kovrizhka II, Invflidnyi III); G - Ust-Karenga geoarchaeological complex (map by E. M.Ineshin)

Comparing the ancient ceramics of the Ust-Karenga archaeological complex with the materials of the well-known archaeological sites of Japan, China, South Korea, Primorye and the Amur River region, we can note its high quality both in manufacture technology (quality of the ceramic paste, consistency in the size of vessels, variable shape) and richness of decorations. Such characteristics are not observed in any other archaeological site with the oldest ceramics in East Asia.

Unfortunately, due to the fragmentary preservation of the vessels in other archaeological complexes in East Asia, we cannot fully compare the oldest ceramics of the Ust-Karenga complex with other sites (by shape, size, ornamentation, and functional use). Very provisionally, it can be stated that if compared to the finds from coastal territories including Amur regions, simple pointed-bottom ovoidal forms of vessels dominate the ceramics of the sites of the inland region (namely, Ust-Karenga III, XII, XIV, XVI, Ust-Yurmuren VIII, Octorocon 1, Studenoe 1, Ust-Menza 1) (see Fig. 5). In the coastal and Amur areas of this center of the most ancient pottery, vessels with flat or, rarely, with convex/rounded bottom are more common (see Fig. 2).

It can also be noted that from the point of view of the landscape and environmental conditions observed in the locations of sites with the most ancient ceramics in the 
Vitim and Chikoy, they occupy niches with the same environmental properties. This inland region was characterized by the presence of local mountain glaciers from 15,000 to 9,000 years ago with near-glacial mosaic plant-faunal complexes that were exploited by the ancient population ${ }^{28}$. On Vitim, this was further complicated by the emergence and long existence of a dammed lake, whose area was nearly a half of lake Baikal one ${ }^{29}$. Such large water mass had a significant impact not only on the plant and animal communities that inhabited their surroundings, but also on the activities of the ancient population and their adaptations to the local environments. In some cases, subsistence practice of the inland hunters that involved the formation and development of the tradition of the use of pottery had, in a certain sense, common features with that of the coastal regions of China, Korea, and the Japanese islands. In particular, this is the exploitation of fish resources as indicated by the high content of nitrogen isotopes in the bone tissues of the ancient inhabitants of the region and sufficiently large amount of fish remains in the composition of the faunal collections of archaeological sites.

The description of the physical appearance of the ceramics-bearing culture of the inland East Asia would not be complete without the information on their stone industry. It has to be stressed that it fully preserves the major characteristics of the features of the socalled "final Paleolithic" tradition based on the use of both bifacial tools and microblades. Its elements are observed, in general, from the Yenisei in the west to the Pacific coast, including the Japan Islands and Sakhalin, in the east. By meridian, their presence is noted in East Siberian materials up to the coast of the Arctic Ocean in the north to the regions of China in the south (see Fig. 1).

The main features of this tradition are the production of bifacial tools which were easy to carry on. As for the function, these were knives, large side scrapers, and possibly large points used to equip thrusting spears. If necessary, all these items could be easily turned into the preforms of narrow faced cores (end cores) to produce microblades to be used as side blades for composite osseous tools, such as spear points and knives. Given the logic of the function, this principle could be described as "three in one". Such tools were often made of high-quality lithic raw materials.

The second important feature of this tradition, derived from the first one, is the high development and wide use of side-blade technology seen in composite tools in which both osseous and lithic materials are combined (see Fig. 3$)^{30}$. The wedge-shaped cores including the micro-cores of the same type are the most important marker of that tradition. More precisely, these are end cores whose platforms are prepared by a single longitudinal removal or by a series of removals taken off from the laterals (see Fig. 4). A specific complex of tools for bone processing presented by different burins (transversal and angle burins) constitutes another peculiar feature of this tradition.

Knapping technology based on wedge-shaped cores made of fragmented bifacial tools is not concluded with that but includes additionally core preparation procedures which al-

${ }^{28}$ Ineshin E.M. Dinamika razvitiia lednikovykh obstanovok i zaselenie chelovekom BaikaloPatomskogo nagoria v pleistotsene - rannem golotsene // Izvestiia laboratorii drevnikh tekhnologii. Irkutsk, 2003. Iss. 1. P. 50-57.

${ }^{29}$ Kulchitskii A.A., Skovitina T.M., Ufimtsev G.F. Plotinnye ozera v dnishchakh riftov Vostochnoi Sibiri: svidetelstva iz proshlogo i veroiatnost' v budushchem. P. 61-65; Margold M., Jansson K. N. Glacial geomorphology and glacial lakes of central Transbaikalia, Siberia, Russia. P. 18-30.

30 Ineshin E.M., Tetenkin A. V. Chelovek i prirodnaia sreda severa Baikal'skoi Sibiri v pozdnem pleistotsene. Mestonakhozhdenie Bol'shoi Iakor' I. Novosibirsk, 2010. 
low repeating of the same steps of knapping to produce microblades. After $\sim 10000$ years ago, at a time of the late Ust-Karenga ceramic tradition, wedge-shape core technology was supplemented by prismatic blade technology with microblades being taken off the whole perimeter of the core front, or from the most part of it. Starting from cultural horizon 6 of Ust-Karenga site microprismatic knapping dominates in the lithic contexts, but that does not exclude using the wedge-shape cores at the same time. Among osseous tools, bone parts of inset tools, fish spears of diverse size and shape, and needles should be mentioned.

For the most of the researchers, knapping technology based on wedge-shaped core serves as a clear signature of the late Upper Paleolithic which unequivocally does not have any ceramics ${ }^{31}$. This point of view is absolutely prevalent and does not even require supporting citation, which would be endless, and thus we leave it aside as it needs separate lengthy discussion. In brief, these technological principles are described as common in archaeological materials assigned to the so-called Duktay paleolitic culture spread in Yakutia, or, according to other? Opinions, recognized in the materials of Selemdzha culture in the Amur River region ${ }^{32}$. It is also seen in the archaeological materials of Verkholensk culture in the Baikal region ${ }^{33}$. In any case, this is a clearly wide-spread cultural phenomenon.

The Ust-Karenga archaeological complex enables to raise the question of the emergence and the early development of the tradition of ancient ceramics in greater details than it is possible for the above-mentioned materials. In the Vitim river basin, there are archaeological sites which are contemporaneous to ceramic-bearing cultural layers of Ust-Karenga sites, but with no ceramics in cultural contexts. Similar to Ust-Karenga complex, these are stratified sites whose cultural materials are included in alluvial deposits. These sites are located at a distance of $600-750 \mathrm{~km}$ from Ust-Karenga. At one of the most studied monuments of this circle (Bolshoi Yakor I, cultural horizon 21), bone remains are well preserved, which made it possible to obtain additional data on hunting preference and seasonality, and estimate their occupation length, and thus suggest their place and role in adaptation strategy used by their inhabitants.

The chronology of the major sites of the Vitim valley is well supported by radiocarbon data. These are, first of all, Bolshoi Yakor I, Invalidniy III, Kovrizhka II and III (see Fig. 2) ${ }^{34}$. For a number of cultural horizons on the reference site of Bolshoi Yakor I, it was possible to obtain seasonality data based on determining the season by animal teeth, analyzing the tooth growth structures.

It was found that human activity which resulted in the formation of cultural horizons with no ceramics, but contemporary to the cultural horizons of Ust-Karenga that yielded ancient ceramics, took place in a short period of time. This is either late fall (October and

${ }^{31}$ Medvedev G. I. Khoziaistvennyi uklad mezoliticheskogo naseleniia Ust'-Beloi Priangaria // Mezolit Verkhnego Priangaria. Irkutsk, 1971. P. 111-126; Mochanov Iu. A. Drevneishie etapy zaseleniia chelovekom Severo-Vostochnoi Azii. Novosibirsk, 1977.

32 Derevianko A. P., Volkov P. V, Li Kh. Selemdzhinskaia pozdnepaleoliticheskaia kul'tura. Novosibirsk, 1998.

${ }_{33}$ Medvedev G. I. Khoziaistvennyi uklad mezoliticheskogo naseleniia Ust'-Beloi Priangaria. P. 111126; Aksenov M. P.: 1) Issledovaniia doneoliticheskikh kompleksov na Verkhnei Lene // Baikal'skaia Sibir' v drevnosti. Irkutsk, 1995. P.45-60; 2) Arkheologicheskaia stratigrafiia i posloinoe opisanie inventaria Verkholenskoi gory 1 // Mezolit verkhnego Priangaria. Pamiatniki Irkutskogo raiona. Irkutsk, 1980. P.4593.

${ }^{34}$ Ineshin E.M., Tetenkin A.V. Chelovek i prirodnaia sreda severa Baikal'skoi Sibiri v pozdnem pleistotsene. Mestonakhozhdenie Bol'shoi Yakor' I. P. 52-55. 
November) or late spring (April and May). The composition of stone and bone equipment of cultural horizons varies depending on the season of the year ${ }^{35}$. The estimated time period of the existence of the camps is presumed to have varied from a single day to several weeks, which was typical of hunting camps on the migration routes of herd animals. Based on this, the cultural horizons of the Bolshoi Yakor I and that of the Invalidniy III site were identified as temporary hunting camps on the path of seasonal migration of herd animals (see Fig. 5).

The study of animal bone remains resulted from hunting and food utilization of the hunting prey by the inhabitants of the site demonstrated that only small mammals and fish were fully consumed. In larger animals, only little transportable body parts with low food value, such as heads, lower parts of legs, and, apparently, liver ${ }^{36}$ was used on the spot. The most valuable body parts were clearly taken outside the sites, possibly as a food supply for the group members who stayed in the base camps ${ }^{37}$, and then transported to such locations. Archaeological contexts of the Ust-Karenga complex that are regarded as cultural horizons 7, 6, 5, and 4 could be perceived as an example of that.

However, the question of the origin and roots of the East Asian ceramics tradition remains open. If radiocarbon dates were put on the map on condition that the old dates for pottery ware from Xianrendong Cave (Jiangxi Province, southern China) ${ }^{38}$ are correct, it could be concluded that the emergence of the ceramic tradition may have taken place in the south and then spread northward. To a certain degree, this is in agreement with dualistic hypothesis of the introduction of the oldest pottery as recently proposed by Jordan et al. ${ }^{39}$ This is very provisional estimate but indeed the question of the origins of the ceramics requires true interdisciplinary approach, and thus it should involve various data including physical anthropology and paleogenetics, first of all, because technological knowledge could be transmitted from people to people, and therefore, most probably could have been transferred within relatively close population group. Inter-group knowledge transmission is also possible, but this requires some mediators to facilitate this exchange.

The physical appearance of the bearers of the early ceramic tradition remains almost totally unknown. Fossil human remains of this time are known very little, and they are poorly studied. Remains of Dzhilinda man, whose burial was excavated at the site of Lower Dzhilinda (Sivakon) at distance of $1280 \mathrm{~km}$ away from the Ust-Karenga archaeological complex $^{40}$ (see Fig. 5) help to fill the gap and give clues both for anthropology and for genetics.

35 Ineshin E.M., Tetenkin A.V. Chelovek i prirodnaia sreda severa Baikal'skoi Sibiri v pozdnem pleistotsene. Mestonakhozhdenie Bol'shoi Yakor' I. P. 233.

${ }^{36}$ Ineshin E.M. Dinamika razvitiia lednikovykh obstanovok i zaselenie chelovekom BaikaloPatomskogo nagoria v pleistotsene - rannem golotsene. P. 50-57.

${ }^{37}$ Ineshin E. M., Tetenkin A.V. Chelovek i prirodnaia sreda severa Baikal'skoi Sibiri v pozdnem pleistotsene. Mestonakhozhdenie Bol'shoi Yakor' I. P. 235, 242-246.

38 Wu X., Zhang C., Goldberg P., Cohen D., Pan Y., Arpin T., Bar-Yosef O. Early Pottery at 20,000 Years Ago in Xianrendong Cave, China // Science. 2012. Vol. 336, iss. 6089. P. 1696-1700.

39 Jordan P., Gibbs K., Hommel P., Piezonka H., Silva F., Steele J. Modelling the diffusion of pottery technologies across Afro-Eurasia: emerging insights and future research // Antiquity. 2016. Vol. 90, iss. 351. P. 590-603.

40 Vetrov V.M, Zadonin O. V., Ineshin E.M. Mnogosloinoe mestonakhozhdenie Nizh. Dzhilinda (Sivakon) - 1 v Bambuiskoi kotlovine // Kul'tury i pamiatniki epokhi kamnia i rannego metalla Zabaikal'ia. Novosibirsk, 1993. P.98-112. 
Several radiocarbon dates run on the human bone samples from this burial (both conventional and AMS $\left.{ }^{14} \mathrm{C}\right)$ produced ages between $7230 \pm 40(\mathrm{GIN}-4051)$ and $7630 \pm 30$ (Beta-432255). This interval corresponds to the late stage of the ancient pottery ware tradition with stepping comb decoration. Although pottery fragments of the ancient type were not found exactly in the burial, lithic artifacts made of exotic rocks were discovered, which is typical in general for the Early Neolithic burials in Asia. The same exotic raw materials come from Ust-Karenga where they are present in cultural horizon 7 (combined horizon). These are jasper-like rocks of dark gray to deep black color found in horizons 5 and 6 as well. In addition, a prismatic core made of dark brown jasper was excavated from the burial. Exactly the same jasper was found in various horizons of the Bolshoi Yakor I site (cultural horizon 3B), as well as in the cultural layers of Invalidniy III and

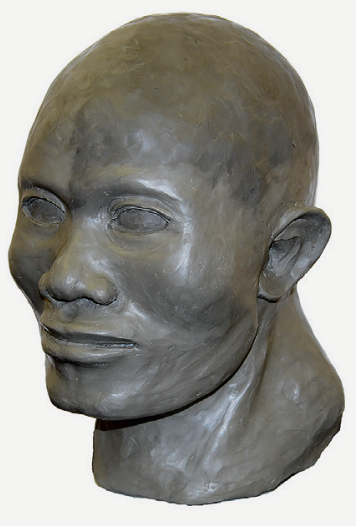

Fig. 6. Low Dzhilinda I (Sivakon site) man (plastic reconstruction by D. V. Pezhemskiy) Kovrizhka I sites ${ }^{41}$. Indirectly, these observations provide some grounds to draw a connection between human fossils unearthed at Low Dzhilinda and population groups that produced ceramics of the most ancient type.

Thanks to the plastic reconstruction of the Dzhilinda man based on the M. M. Gerasimov's method ${ }^{42}$ performed by anthropologist D. V. Pezhemsky, the physical appearance together with the results of cranioscopic study allowed D. V. Pezhemsky to suggest South Asian origin of that individual (Fig. 6) ${ }^{43}$. The genetics study of the bone remains of Dzhilinda Man by the research team led by M. Götherström (Götherström, personal communication: preliminary conclusions reported to the author) enabled to identify Y-chromosome which belongs to Y-chromosome Hg C2bla.

This demonstrates South Asian origin of this individual seen both in male and female lineages as it is confirmed by the identification of mtDNA haplogroup (C5c) and thus indicates South Asian origin of the bearers of the ancient pottery ware tradition. Replication of the result (i.e., the same direction of the gene flow both in mtDNA and in Y-chromosome) could be interpreted as the evidence of certain isolation of this population group from other inhabitants of the area. The results of the study performed on mitochondrial genome of the Dzhilinda man do not contradict this ${ }^{44}$. It's possible to hypothesize that this group either tended to avoid other inhabitants, or the territory was very scarcely populated.

Additionally, it is found that bone tissues of the Dzhilinda individual contain nitrogene isotopes in relatively high numbers $(\mathrm{d} 15 \mathrm{~N}=+12,2 \%$ ), which indicates high amount of fish in the diet of the ancient population of the Vitim river basin. This observation

41 Vetrov V.M. Ritualnyi kompleks v uste r. Karenga (dolina r.Vitim) i nekotorye problemy neolita Vostochnoi Sibiri // Izvesti laboratorii drevnikh tekhnologii. 2008. Iss. 6. P. 28-43.

${ }^{42}$ Gerasimov M. M. Vosstanovlenie litsa po cherepu: (sovremennyi i iskopaemyi chelovek). Moscow, 1955.

43 Pezhemskii D. V., Rykushina G. V. Chelovek iz Nizhnei Dzhilindy (predvaritel'noe soobshchenie) // Vestnik antropologii. 1998. Iss. 5. P.115-135.

${ }^{44}$ Kılınç G. M., Kashuba N., Yaka R. et al. Investigating Holocene human population history in North Asia using ancient mitogenomes // Scientific Reports, 2018. Vol. 8 (1). P. 8969. 
is also supported by findings of fish bones in cultural horizon 7 (combined horizon) at Ust-Karenga site complex ${ }^{45}$.

In sum, the combination of these data does not contradict the assumption that the ancient ceramics tradition in the Vitim basin, whose evidence is found at Ust-Karenga XII, XIV, and XVI localities and in the Chikoy river where it is yielded by several site, namely Studenoe 1 (cultural horizon 8) and Ust-Menza 1 (cultural horizon 8), appears to have been the result of transmitting of knowledge in the south-north direction (see Fig. 2), or it could have been the result of human migration. The possible initial area of distribution of the most ancient pottery can be recognized as the territory limited by Xianrendong - Yuchanyan - Baozitou sites in southeast China (see Fig. 1, 2) ${ }^{46}$.

Recently, with the expanding of archaeological investigations in the north-eastern Asia, new archaeological sites produced an evidence for the oldest ceramic production. For example, the Krasnaya Gorka site on the Bolshoe Eravninsky Lake on the southeast face of the Vitim Plateau, $390 \mathrm{~km}$ from the Ust-Karenga archaeological complex, was discovered $^{47}$ and partially investigated (see Fig. 1). According to the published data, ceramics dates to $11150 \pm 50$ (AAR-21437) - $12010 \pm 60$ (Poz-68-608). It also has a number of key indicators in shape and size of the vessels, some details of the manufacturing technology, and thus it is very similar to the oldest ceramics of Ust-Karenga, being contemporaneous to it, too. The lithic material of the site has practically the same technical and typological indicators similar to the stone industry of the Ust-Karenga archaeological complex (bifacial techniques in different variants, from bifacial tools to biface core preforms, transversal burins, large side scrapers, microblades ${ }^{48}$.

These findings show that as scientific research steps forward, the number of archaeological objects with traces of ancient pottery should increase. Assessing the situation with the oldest ceramics in Eastern Asia and the Eurasian continent as a whole, it is necessary to emphasize that its invention and then distribution worldwide greatly expanded the adaptive capabilities of ancient humans. Presumably, it emerged and reached significant heights in the east of Eurasia, and only then reached the Middle East and North Africa. There are no direct data that would allow asserting that the very idea of ceramics, having arisen in the east, then spread to the west. Perhaps, in the Middle East region or in North Africa, the idea of making ceramics was formed independently of the East Asian Center, but the current state of knowledge suggests that the East was, at least, its ancestral home. From there, from the East, and in subsequent epochs, well-known useful innovations spread over the world repeatedly: not only ceramics, but also porcelain, compass, gunpowder, paper, and other technologies.

45 Stock J. T., Bazaliiskii V. I., Goriunova O. I., Savelev N. A, Weber A. W. Skeletal Morphology, Climatic Adaptation, and Habitual Behavior among Mid-Holocene Cis-Baikal Populations // Prehistoric HanterGetherers of the Baikal Region, Siberia: bioarchaeological studies of past life ways. Philadelphia, 2010. P. 180-191.

46 Sato H., Natsuki D. Human behavioral responses to environmental condition and the emergence of the world's oldest pottery in East and Northeast Asia: An overview. P. 12-28.

47 Tsydenova N., Andreeva D., Zech W. Early pottery in Transbaikal Siberia: New data from Krasnaya Gorka. P. 81-90.

${ }^{48}$ Ineshin E. M., Tetenkin A. V. Chelovek i prirodnaia sreda severa Baikalskoi Sibiri v pozdnem pleistotsene. Mestonakhozhdenie Bol'shoi Yakor' I. P. 85. 


\section{Conclusions}

Several important conclusions based on Ust-karenga materials discussed in the broad context of archaeological, anthropological, genetics and environmental data can be drawn, such as

1. The East Asian center of the origin and development of the oldest ceramics is the oldest center of the origin of ceramic production. Archaeological sites whose contexts contain the oldest pottery ware belong to coastal (e. g., Hummi, Gassia, Goncharka, Gromatuha, Osipovka, Chernigovka 1, Ustinovka 3) and to the inland zone (that is, Ust-Karenga XII, XIV, XVI, Ust-Yurmchen VIII, Ust-Menza 1, Studenoe 1, Krasnaya Gorka).

2. The appearance and existence of the oldest ceramics in these zones reflect the specific adaptations of the ancient Asian population necessary for further development of the hunter-gatherer economy, which was expressed in the development of a flexible form of organization of human groups. It can be assumed that their groups were divided into relatively settled groups and moving "harvesters". The latter carried out the harvesting of food supplies and exotic rocks of stone raw materials in areas adjacent to mountains, still partially covered by mountain-valley glaciers with subalpine plant stations rich in food resources. Food stocks and raw materials, often in the form of various artifacts, were transported to the sites (e. g., jasper, quartz crystal, pumice-stone, graphite, red ochre).

3. Hunting species used by these people were mainly herd animals migrating from winter habitats to summer ones, such as reindeer, red deer, elk, horse, bison, but also arctic fox, hare, ptarmigan, waterfowl, wolf and brown bear. Fish catching also played an important role. Perch, pike, and sturgeon were more common. Presumably, by this time fishing traps of wicker twigs or a bark had already been known.

4. Ceramic vessels, in most cases, served as containers for food storage, but they also were used as cookware to process raw meat. In some cases, ceramic vessels were repaired after they had cracked, by tight stitching the fragments with some organic fibers through drilled holes. Further use of repaired vessels for processes which would involve heating (e.g., cooking) was impossible. This means that in some cases vessels were of high value as its replacement was impossible, for whatever reason. Thus, from the point of view of the activity approach, they denote the stationary, relatively long-term camps of ancient hunters, where the permanent inhabitants were few mobile members of the collectives. In terms of lithic technology, there is no difference between base camps with ceramics (Ust-Karenga XII, XIV and XVI, horizons 3, 4, 5, 6; Ust-Yumurchen-VIII, mountain 4; Studenoe-1, mountains 8-9; Ust-Menza-1, mountains 8) and temporary seasonal sites used by hunting groups sent to harvest, which had no ceramics in their contexts (Bolshoi Yakor I, Kovrizhka II, III, and IV, Invalidniy III). Bifacial technology and production of microblades for insert tools seem to have been the main characteristics of lithic industry of these sites. Bifacial tools (large side scrapers and knives) were at the same time the preforms for end-cores for microblades. This tool kit based on "three in one" principle is easy to carry and gives all necessary options for long-distance travels. Bifacial processing and compact forms of bifacial implements are in this context ideal adaption that perfectly suits hunting on seasonally migrating animal species in the conditions of tundra-steppes and mountain alpinoid tundra-steppes with mosaic taiga forest.

5. Migrating groups of hunter-harvesters transported not only hunting products (fillet parts of animal corpses), but also high-quality lithic raw materials in the form of 
finished products, such as bifaces or extremely rarely rock nodules. Sources of raw materials were located along the path of movement of groups of hunter-harvesters who exploited the migration routes of large animals. Thus, the pattern of spatial distribution of exotic lithic raw materials in the region becomes a map of seasonal migrations of hunters in the past following migrations of the prey species. Importantly, they had been able to transmit through time the knowledge of the location of high-quality lithic raw materials as well the tradition of ceramic production. Probably, this may indicate genetically homogeneous population.

6. According to the most recent data from paleogenetics and anthropology of the ancient population revealed for the territory of Baikal region of Siberia and Yakutia, the bearers of the tradition of making and using the most ancient ceramics had roots in southern regions of Asia (see Fig. 6). This is also confirmed by anthropological and genetic analysis of Dzhilinda man discovered in the Vitim river basin.

This study, once again, demonstrates that "European" approach to Asian archaeological materials is not really productive and often leads to a deadlock. It seems that the academic community of various scholarly schools in South Korea, China, Russia, and Japan faces the great challenge of developing an adequate nomenclature for describing and understanding the very specific ancient history of the Asian continent.

\section{References}

Aksenov M. P. Arkheologicheskaia stratigrafiia i posloynoe opisanie inventaia Verkholenskoy Gory 1. Mezolit Verkhnego Priangar'ya. Pamyatniki Irkutskogo rayona. Irkutsk, IGU, 1980, pp. 45-93. (In Russian)

Aksenov M. P. Issledovaniia doneoliticheskikh kompleksov na Verkhney Lene. Baikal'skaia Sibir'v drevnosti. Irkutsk, IGPI, 1995, pp.45-60. (In Russian)

Gerasimov M. M. Vosstanovlenie litsa po cherepu: (sovremennyi i iskopaemyi chelovek). Moscow, Izdatel'stvo Akademii Nauk SSSR, 1955, 585 p. (In Russian)

Demonterova E. I., Ivanov A. V., Ineshin E. M., Teten'kin A. V. K voprosu o mobil'nosti drevnego naseleniia severa Baikal'skoi Sibiri v kontse pleystotsena. Stratum plus, 2014, no. 1, pp. 165-180. (In Russian)

Derevianko A. P., Volkov P. V, Li K. Selemdzhinskaia pozdnepaleoliticheskaia kul'tura. Novosibirsk, IAET SO RAN, 1998, 335 p. (In Russian)

Hommel P.N., Schwenninger J.-L., Ineshin E.M., Vetrov V.M. Testing times: an evaluation of the radiocarbon chronology for early ceramic vessel production at Ust'-Karenga. Izvestiia laboratorii drevnikh tekhnologiy, 2017, vol. 13, no. 1, pp.31-46.

Ineshin E.M. Dinamika razvitiia lednikovykh obstanovok i zaselenie chelovekom Baikalo-Patomskogo nagoria $\mathrm{v}$ pleistotsene - rannem golotsene. Izvestiia laboratorii drevnikh tekhnologii. Iss. 1. Irkutsk, Izdatel'stvo IrGTU, 2003, pp. 50-57. (In Russian)

Ineshin E. M., Teten'kin A. V. Chelovek i prirodnaia sreda severa Baykal'skoy Sibiri v pozdnem pleystotsene. Mestonakhozhdenie Bol'shoy Yakor' I. Novosibirsk, Nauka, 2010, 270 p. (In Russian)

Jordan P., Gibbs K., Hommel P., Piezonka H., Silva, F., Steele, J. Modelling the diffusion of pottery technologies across Afro-Eurasia: emerging insights and future research. Antiquity, 2016, vol.90, iss. 351, pp. 590-603.

Kılınç G. M., Kashuba N., Yaka R., Sümer A.P., Yüncü E., Shergin D., Ivanov G., Kichigin D., Pestereva K., Volkov D., Mandryka P., Kharinskii A., Tishkin A., Ineshin E., Kovychev E., Stepanov A., Alekseev A., Fedoseeva S., Some M., Jakobsson M., Krzewińska M., Storå J., Götherström A. Investigating Holocene human population history in North Asia using ancient mitogenomes. Scientific Reports, 2018, vol. 8 (1), pp. 8969.

Konstantinov M.V. Kamennyi vek vostochnogo regiona Baikal'skoi Azii. Ulan-Ude; Chita, Institut obshchestvennykh nauk BNTS SO RAN, 1994, 163 p. (In Russian) 
Konstantinov M.V. "I opyt, syn oshibok trudnykh” (problemy opredeleniia vozrasta drevnikh poselenii Zabaikal'ia). Drevnee Zabaikal'e: kul'tura i priroda. Ed. by M. V. Konstantinov. Chita, 2009, pp. 35-42. (In Russian)

Kul'chitskiy A.A., Skovitina T.M., Ufimtsev G.F. Plotinnye ozera v dnishchakh riftov Vostochnoi Sibiri: svidetel'stva iz proshlogo i veroyatnost' v budushchem. Geografiia i prirodnye resursy, 1997, no. 1, pp. 61-65. (In Russian)

Kuzmin Y. V. The origins of pottery in East Asia and neighboring regions: An analysis based on radiocarbon data. Quaternary International. 2017, vol. 441B, pp. 29-35.

Kuzmin Y.V. Proiskhozhdenie keramiki v Evrazii: sovremennoe sostoianie voprosa. Rossiiskii arkheologicheskii ezhegodnik, 2013, no. 3, pp. 8-26. (In Russian)

Kuzmin Y., Vetrov V. The earliest Neolithic complex in Siberia: the Ust-Karenga 12 site and its significance for the Neolithization process in Eurasia. Documenta Praehistorica, 2007, no. 24, pp. 9-20.

Margold M., Jansson K. N. Glacial geomorphology and glacial lakes of central Transbaikalia, Siberia, Russia. Journal of Maps, 2011, vol. 7 (1), pp. 18-30.

Medvedev G. I. Khoziaistvennyi uklad mezoliticheskogo naseleniia Ust'-Beloy Priangar'ia. Mezolit Verkhnego Priangar'ia. Irkutsk, Irkutsk State University Publishing House, 1971, pp. 111-126. (In Russian)

Mochanov Y. A. Drevneishie etapy zaseleniia chelovekom Severo-Vostochnoy Azii. Novosibirsk, Nauka, 1977, 264 p. (In Russian)

Myl'nikova L. N., Nesterov S. P. Fiziko-khimicheskoe issledovanie keramiki pamiatnika Kosanni: k probleme proiskhozhdeniia goncharstva. Neolit i neolitizatsiia basseina Iaponskogo moria: chelovek $i$ istoricheskii landshaft: Materialy mezhdunarodnoi arkheologicheskoi konferentsii, posviashchennoi 100-letiiu so dnia rozhdeniia A.P. Okladnikova. Vladivostok, Dal'nevostochnyi Universitet, 2008, pp. 161-165. (In Russian)

Pezhemskiy D. V., Rykushina G. V Chelovek iz Nizhney Dzhilindy (predvaritel'noe soobshchenie). Vestnik antropologii, 1998, iss. 5, pp.115-135. (In Russian)

Razgil'deeva I.I., Kunikita D., Yanshina O.V. Novye dannye o vozraste drevneyshikh keramicheskikh kompleksov zapadnogo Zabaykal'ia. Eurasia in Cenozoic Era. Stratigraphy, paleoecology, cultures, 2013, iss. 2, pp. 168-178. (In Russian)

Sato H., Natsuki D. Human behavioral responses to environmental condition and the emergence of the worlds oldest pottery in East and Northeast Asia: An overview. Quaternary International, 2017, vol. 441, pp. 12-28.

Stock J.T., Bazaliiskii V.I., Goriunova O.I., Savel'ev N.A., Weber A.W. Skeletal Morphology, Climatic Adaptation, and Habitual Behavior among Mid-Holocene Cis-Baikal Populations. Prehistoric HanterGetherers of the Baikal Region, Siberia: bioarchaeological studies of past life ways. Philadelphia, 2010, pp. 180-191.

Tsydenova N., Andreeva D., Zech W. Early pottery in Transbaikal Siberia: New data from Krasnaya Gorka. Quaternary International, 2017, vol.441, pp. 81-90.

Wu X., Zhang C., Goldberg P., Cohen D., Pan Y., Arpin T., Bar-Yosef O. Early Pottery at 20,000 Years Ago in Xianrendong Cave, China. Science, 2012, vol. 336, iss. 6089, pp. 1696-1700.

Vetrov V.M. Drevneishie sledy keramicheskogo proizvodstva v Vostochnoi Azii. Antropogen. Paleontropologiya, geoarkheologiia, etnologiia Azii. Ed. by G. I. Medvedev. Irkutsk, Ottisk, 2008, pp. 28 34. (In Russian)

Vetrov V. M. Ritual'nyi kompleks v ust'e r. Karenga (dolina r.Vitim) i nekotorye problemy neolita Vostochnoi Sibiri. Izvestiia laboratorii drevnikh tekhnologii, 2008, iss. 6, pp. 28-43. (In Russian)

Vetrov V.M., Ineshin E.M., Revenko A.G., Sekerin A.P. Artefakty iz ekzoticheskikh vidov syr'ia na arkheologicheskikh pamiatnikakh Vitimskogo basseina. Baikal'skaia Sibir'v drevnosti, 2000, iss.2, part 1, pp.98-117. (In Russian)

Vetrov V. M., Zadonin O. V., Ineshin E. M. Mnogosloinoe mestonakhozhdenie Nizh. Dzhilinda (Sivakon) $1 \mathrm{v}$ Bambuyskoy kotlovina. Kul'tury i pamyatniki epokhi kamnia i rannego metalla Zabaykal'ia. Novosibirsk, Nauka, 1993, pp.98-112. (In Russian)

Zinov'ev A. A. Na puti k sverkhobshchestvu. Moscow, Tsentrpoligraf, 2000, 260 p. (In Russian)

Zhushchikhovskaya I.S. Drevneishaia keramika: puti tekhnologicheskoi innovatsii. Vestnik DVO RAN. Arkheologiia, 2011, no. 1, pp.101-110. (In Russian)

Статья поступила в редакцию 17 мата 2018 г. Рекомендована в печать 12 марта 2019 г.

Received: March 17, 2018

Accepted: March 12, 2019 